\title{
In-Vitro Anti-Fungal Activity and Phytochemical Screening of Stem Bark Extracts from Ventilago denticulata
}

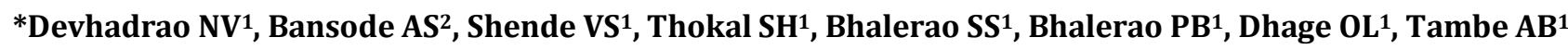 \\ 1 Sharadchandra Pawar College of Pharmacy, Dumbarwadi, Otur. (Pune)-412409 Maharashtra, India. \\ 2 Vjsm's Vishal Institute of Pharmaceutical Education and Research Ale, Junnar (Pune) Maharashtra, India.
}

\begin{abstract}
The objective of the present study was to assess the antifungal activity of pet. Ether extract, acetone extract, ethyl acetate, and ethanol bark extract of Ventilago denticulata (VD).The material was dried in shade made to a coarse powder and weighted quantity of the powder (1000 g) was subjected to hot percolation in a soxhlet apparatus using petroleum ether, ethyl acetate, acetone and ethanol, at a temperature range of 40 $80^{\circ} \mathrm{C}$. Phytochemical tests were done in presence of phytoconstituents like glycosides, alkaloids, tannins, steroids, flavonoids. The anti-fungal activity was carried out by using cup method using Sabraud's agar as medium. Plates were incubated at $25^{\circ} \mathrm{C}$ for $42 \mathrm{hr}$ and later observed for zones of inhibition. The effect of the extracts on fungal isolates was compared with Griseofluvin at a concentration of $10 \mathrm{mg} / \mathrm{ml}$. The Ethyl acetate extract at low as well as high doses gives antifungal effect. Pet-ether extract, acetone extract and ethanolic extract did not produce any antifungal effect at both doses. Ethyl acetate extract shows zone of inhibition at low dose ( $\left.\mathrm{T}_{1} 10 \mathrm{mg} / \mathrm{ml}\right) 10 \mathrm{~mm}$ and at high dose ( $\left.\mathrm{T}_{2} 20 \mathrm{mg} / \mathrm{ml}\right)$ $16 \mathrm{~mm}$.
\end{abstract}

Keyword: Ventilago denticulata, Anti- fungal, Griseofluvin.

Article Info: Received 09 June 2019; Review Completed 19 July 2019; Accepted 20 July 2019; Available online 15 August 2019

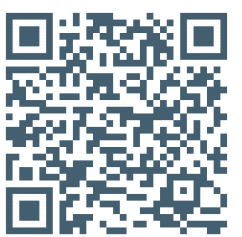

Cite this article as:

Devhadrao NV, Bansode AS, Shende VS, Thokal SH, Bhalerao SS, BhaleraoPB, Dhage OL, Tambe AB, In-Vitro Anti-Fungal Activity and Phytochemical Screening of Stem Bark Extracts from Ventilago denticulata, Journal of Drug Delivery and Therapeutics. 2019; 9(4-s):359-362 http://dx.doi.org/10.22270/jddt.v9i4-s.3326

Mr. Devhadrao Nitin V., Sharadchandra Pawar College of Pharmacy, Dumberwadi, Otur (Pune) Pin code: 412409.

\section{INTRODUCTION}

Traditional medicines initially took the form of crude drugs such as tinctures, teas, poultices, powders, and other herbal formulations ${ }^{1}$.The specific plants to be used and the methods of application for particular ailments were passed down through oral tradition. Plants with possible antimicrobial activity should be tested against some microbes to confirm the activity. The activity of plant extracts on bacteria and fungi has been studied by a very large number of researchers in different parts of the world 2,3 . As a result, antifungal therapy is playing a greater role in health care and the screening of traditional plants in search of novel antifungal is now more frequently performed 4 . The selection of crude plant extracts for screening programs has the potential of being more successful in initial steps than the screening of pure compounds isolated from natural products 5 . Fungal diseases represent a critical problem to health and they are one of the main causes of morbidity and mortality worldwide 6 . Human infections, particularly those involving the skin and mucosal surfaces, constitute a serious problem, especially in tropical and subtropical developing countries ${ }^{7}$.
In humans, fungal infections range from superficial to deeply invasive or disseminated, and have increased dramatically in recent years. The treatment of mycoses has lagged behind bacterial chemotherapy and fewer antifungal than antibacterial substances are available. Therefore, a search for new antifungal drugs is extremely necessary ${ }^{8}$. During the past several years, there has been an increasing incidence of fungal infections due to a growth in immune compromised population such as organ transplant recipients, cancer and HIV/AIDS patients ${ }^{9,10}$. This fact coupled with the resistance to antibiotics and with the toxicity. Pathogenic fungi, dermatophytes, have the ability to invade keratinized tissues of animals and humans and cause a disease, dermatophytosis, which is the commonest human contagious fungal disease ${ }^{11,12}$. Trichophyton rubrum (T. rubrum ) is the most prevalent pathogenic fungus worldwide and it represents $80 \%$ of clinical isolates ${ }^{13}$. Due to the increasing development of drug resistance in human pathogens as well as the appearance of undesirable effect of certain antimicrobial agents, there is a need to search for new antifungal agent without toxicity and side effect. Plant extracts or plant-derived compounds are likely to provide a 
valuable source of new medicinal agents 14,15 . Infectious diseases, particularly skin and mucosal infections, are common in most of the tribal inhabitants due to lack of sanitation, potable water and awareness of hygienic food habits. An important group of these skin pathogens are the fungi, among which dermatophytes and Candida spp are prominent 16,17 . Antimicrobial properties of certain Indian medicinal plants were reported based on folklore information $18-25$, and a few attempts were made on inhibitory activity against certain pathogenic bacteria and fungi.

The bark of Ventilago denticulata plant is used traditionally in blood and heart related diseases. The paste of the root bark is applied as a cure for wounds, eye diseases, etc. Stem bark decoction is given with a paste of Piper nigrum Linn. (Black pepper) to treat stomach ulcer. The paste of the stem bark is also applied to relieve body pain. About $25 \mathrm{ml}$ stem bark is administered once a day for yellow urination, stem bark powdered \& mixed with sesame oil, externally applied on skin diseases 26,27 . In the present study, the antifungal activities of pet. Ether extract, acetone extract, ethyl acetate, and ethanol bark extract of Ventilago denticulata plant were investigated against aspergillus niger pathogens.

\section{MATERIALS AND METHODS \\ COLLECTION OF PLANT AND IDENTIFICATION}

The bark of the plant collected from the forest near the malshej ghat Pune India. The sample of Ventilago denticulata Willd. Was identified and authenticated by Dr.S.R.Rahangdale (Botanical Professor, taxonomist in Anna Saheb Wagere College, Otur, Pune India).

\section{PREPARATION OF PLANT EXTRACTS}

Freshly collected bark of the plant Ventilago denticulata Wild. Were washed, shade dried under room temperature for a period of three weeks. The dried plant material was made to a coarse powder and weighted quantity of the powder (1000 g) was subjected to hot percolation in a soxhlet apparatus using petroleum ether, ethyl acetate, acetone and ethanol, at a temperature range of $40-80^{\circ} \mathrm{C}$. Before and after every extraction, the marc was completely dried and weighed. The extracts were concentrated by evaporation of solvent at room temperature. The percentage yield of petroleum ether extract, ethyl acetate extract, acetone extract and ethanol extract were found to be $1.2 \%, 1.4 \%$, $0.8 \%$ and $1.2 \% \mathrm{w} / \mathrm{w}$ respectively ${ }^{28}$.

\section{PRELIMINARY PHYTOCHEMICAL ANALYSIS}

The extracts obtained from Ventilago denticulata bark were subjected to qualitative test for the identification of various plant constituents ${ }^{29}$.

\section{ANTI-FUNGAL ASSAY}

The fungal isolates were allowed to grow on Sabouraud's dextrose agar/broth (SAD) (Oxoid) at $25^{\circ} \mathrm{C}$ until them sporulated. The fungal spores were harvested after sporulation by pouring a mixture of distilled water to the surface of the plate and later scraped the spores with sterile glass rod. The harvested fungal spore isolates were standardized to an OD $600 \mathrm{~nm} 0.1$ before use. One hundred micro liter of the standardized fungal spore suspension was evenly spread on the SDA using a glass spreader. Well were then bored into the agar media. $6 \mathrm{~mm}$ cork borer and the well filled with the solution of the extract taking care not to allow spillage of the solution to the surface of the agar media. Plates were incubated at $25^{\circ} \mathrm{C}$ for $42 \mathrm{hr}$ and later observed for zones of inhibition. The effect of the extract on fungal isolates was compared with Griseofluvin at a concentration of $10 \mathrm{mg} / \mathrm{ml}^{30}$.

\section{Culture Media:}

The media used for antifungal test was Sabouraud's dextrose agar/broth of Hi media Pvt.

Bombay, India.

\section{Inoculum:}

The fungal strains were inoculated separately in Sabouraud's dextrose broth for $6 \mathrm{hr}$ and the

Suspensions were checked to provide approximately 105 $\mathrm{CFU} / \mathrm{ml}$.

\section{Fungal strains used:}

The clinical fungal test organisms used for study are Aspergillus niger ATCC.

\section{RESULT \& DISCUSSION}

In recent years, although technology and medicine have developed extensively, some countries have made it obligatory to use natural products for many different purposes due to decrease in natural richness and drawbacks. Like in many other countries, the plants known by people with health benefits are picked up and used for the treatment of various diseases in India. In this study, the antifungal capacity of the extracts from Ventilago denticulata against fungi was determined.

The antifungal activities of the extracts from the test samples in terms of minimum inhibitory concentrations (MIC) and diameters of inhibition zones are reported. The crude ethyl acetate extract Ventilago denticulata from found to be prominently active against the tested microorganisms at the concentrations $10 \mathrm{mg} / \mathrm{ml}$ and $20 \mathrm{mg} / \mathrm{ml}$. . Ethyl acetate extract shows zone of inhibition at low dose $\left(\mathrm{T}_{1} 10 \mathrm{mg} / \mathrm{ml}\right)$ $10 \mathrm{~mm}$ and at high dose $\left(\mathrm{T}_{2} 20 \mathrm{mg} / \mathrm{ml}\right) 16 \mathrm{~mm}$. (Shown in table-1)

Table -1

\begin{tabular}{|c|c|c|}
\hline \multicolumn{3}{|c|}{ Zone of Inhibition (mm) } \\
\hline Extract & \multicolumn{2}{|c|}{ Aspergillus Niger ATCC } \\
\hline & $\mathrm{T}_{1}(10 \mathrm{mg} / \mathrm{ml})$ & $\mathrm{T}_{2}(20 \mathrm{mg} / \mathrm{ml})$ \\
\hline Pet ether VD & - & - \\
\hline Ethyl acetateVD & $10 \mathrm{~mm}$ & $16 \mathrm{~mm}$ \\
\hline Acetone VD & - & \\
\hline Ethanol VD & - & - \\
\hline
\end{tabular}

Griseofluvin: $15 \mathrm{~m}$

Ventilago denticulata pet. Ether extract, acetone extract and ethanolic extract did not produce any antifungal effect at both doses. Anti-fungal activity was carried out by using cup method using Sabouraud's agar as medium (Shown in Fig.14). 


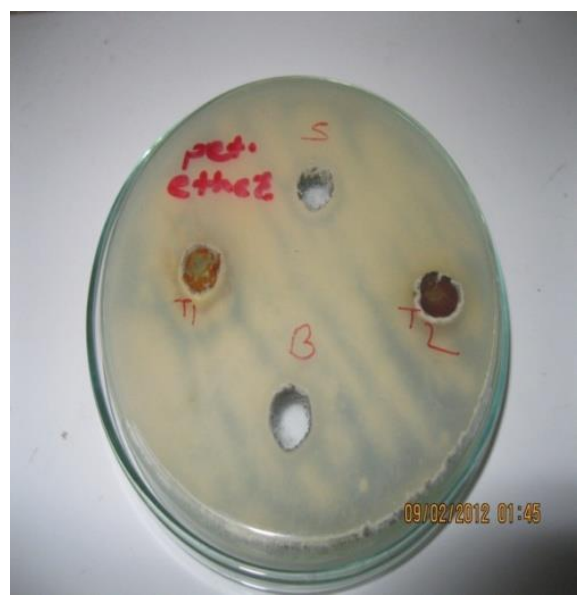

Fig.1- Pet ether extract

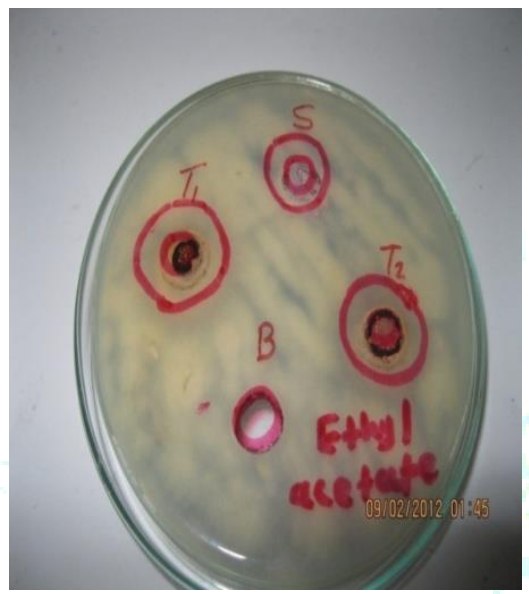

Fig.3- Acetone extract

More studies are required to achieve the proper role of Ventilago denticulata extract to find out more specific biochemical, pharmacological and molecular aspects of the targeted molecules within that may have broadest implication to society.

Investigations on the phytochemical screening of Ventilago denticulata stem bark extracts revealed the presence of glycosides, alkaloids, tannins, flavonoids and steroids. These secondary metabolites exert antifungal activity through different mechanisms. Tannins have been found to form irreversible complexes with proline rich protein ${ }^{30}$ resulting in the inhibition of cell protein synthesis. Tannins are known to react with proteins to provide the typical tanning effect which is important for the treatment of inflamed or ulcerated tissues ${ }^{31}$. Herbs that have tannins as their main components are astringent in nature and are used for treating intestinal disorders such as diarrhea and dysentery ${ }^{32}$. The presence of tannins in Ventilago denticulata supports the traditional medicinal use of this plant in the treatment of different ailments. Another secondary metabolite compound observed in the stem bark extract Ventilago denticulata of was alkaloid. One of the most common biological properties of alkaloids is their toxicity against cells of foreign organisms ${ }^{33}$. Steroidal extracts from some medicinal plants which exhibited antibacterial activities on some bacterial isolates ${ }^{34}$. Flavonoids another constituent of Ventilago denticulata stem bark extracts exhibited a wide range of biological activities like antimicrobial, anti-inflammatory, anti-angionic, analgesic, anti-allergic, cytostatic and antioxidant properties ${ }^{35}$.It is concluded that Ventilago denticulata stem

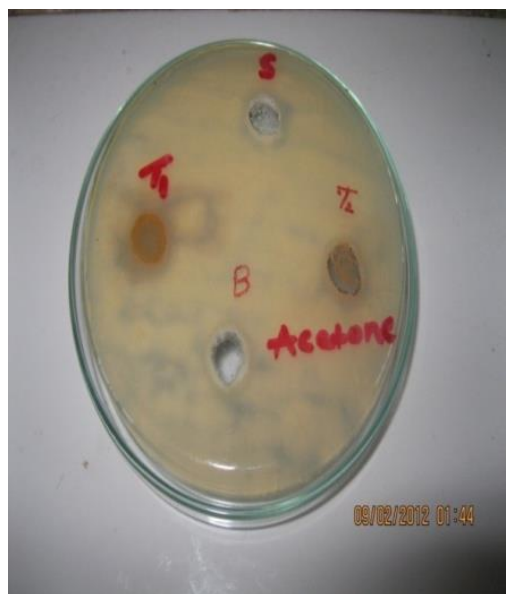

Fig.2- Acetone extract

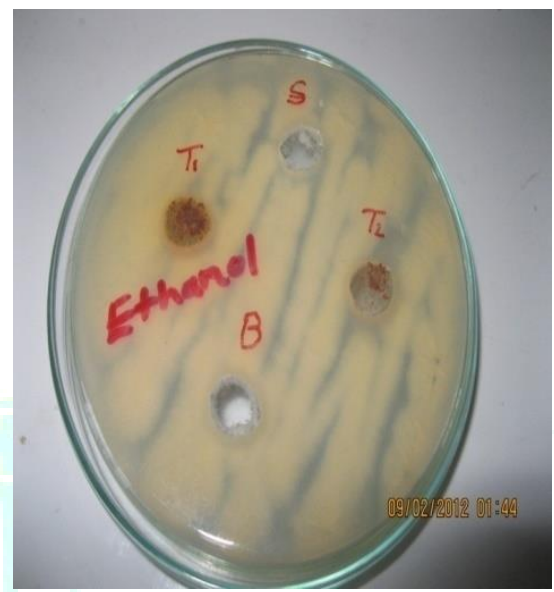

Fig.4 - Ethanol extract

bark could be a potential source of active antimicrobial agents, and a detailed assessment of its in vivo potencies and toxicological profile is ongoing.

\section{ACKNOWLEDGEMENT}

The authors wish to thank Dr. C. Bothiraja for his valuable suggestion in preparing the manuscript and Dr.S.R.Rahangdale for his technical advice. The authors acknowledge the support provided by Dr. Dama G.Y. Principal of Sharadchandra Pawar College of pharmacy, otur pune. Maharashtra

\section{REFERENCES}

[1] Samuelsson G. Drugs of natural origin: a textbook of pharmacognosy. 5th ed. Stockholm: Swedish Pharmaceutical Press; 2004.

[2] Vuuren SFV, Naidoo D. An antimicrobial investigation of plants used traditionally in southern Africa to treat sexually transmitted infections. J Ethnopharmacol 2010; 130: 552-558.

[3] Bhengraj AR, Dar SA, Talwar GP, Mittal A. Potential of a novel polyherbal formulation BASANT for prevention of Chlamydia trachomatis infection. Int J Antimicrob Agents 2008; 32: 8488.

[4] Motsei ML, Lindsey KL, van Staden J, Jager AK. Screening of traditionally used South African plants for antifungal activity against Candida albicans. J Ethnopharmacol 2003; 86: 235241.

[5] Kusumoto IT, Nakabayashi T, Kida H. Screening of various plant extracts used in ayurvedic medicine for inhibitory effects on human immunodeficiency virus type 1 (HIV-1) protease. Phytother Res 1995; 9: 180-184. 
[6] CSIR. Wealth of India, publications \& information directory. New Delhi, India: CSIR; 1998; 164.

[7] Portillo A, Vila R, Freixa B, Adzet T, Canigueral S. Antifungal activity of Paraguayan plants used in traditional medicine. J Ethnopharmacol 2001, 76: 93-98.

[8] Fortes TO, Alviano DS, Tupinamba G, Padron TS, Antoniolli AR, Alviano CS, et al. Production of an antimicrobial substance against Cryptococcus neoformans by Paenibacillus brasilensis Sa3 isolated from the rhizosphere of Kalanchoe brasiliensis. Microbiol Res 2008; 163: 200-207.

[9] Giordani R, Trebaux J, Masi M, Regli P. Enhanced antifungal activity of ketoconazole by Euphorbia characias latex against Candida albicans. J Ethnopharmacol 2001; 78: 1-5.

[10] Fostel J, Lartey P. Emerging novel antifungal agents. Drug Discov Today 2000; 5: 25-32.

[11] Esquenazi D, Alviano CS, DeSouza W, Rozental S. The influence bof surface carbohydrates during in vitro infection of mammalian cells by the dermatophyte Trichophyton rubrum. Res Microbiol 2004; 155: 144 - 153.

[12] Sidat MM, Correia D, Buene TP. Tinea capitis among rural school children of the district of Magude, in Maputo province, Mozambique. Mycoses 2006; 49: 480- 483.

[13] Chan MMY. Antimicrobial effect of resveratrol on dermatophytes and bacterial pathogens of the skin. Biochem Pharmacol 2002; 63: 99-104.

[14] Carvalho PB, Ferreira EI, Leishmaniasis phytotherapy. Nature's leadership against an ancient disease-review. Fitoterapia 2001; 72: 599-618.

[15] Kayser 0, Kiderlen AF. In vitro leishmanicidal activity of naturally occurring chalcones. Phytother Res 2001; 1: 148.

[16] Fan SR, Liu XP, Li JW. Clinical characteristics of vulvovaginal candidiasis and antifungal susceptibilities of Candida species isolates among patients in southern China from 2003 to 2006. J Obstet Gynaecol Res 2008 34(4):561-566.

[17] De Toledo CEM, Britta EA, Ceole LF, Silva ER, De Mello JCP, FilhO BPD, et al. Antimicrobial and cytotoxic activities of medicinal plants of the Brazilian cerrado, using Brazilian cachac, a as extractor liquid. J Ethnopharmacol 2011, 133: 420-425

[18] Tharkar PR, Tatiya AU, Shinde PR, Surana SJ, Patil UK. Antifungal activity of Glycyrrhiza glabra Linn. and Emblica officinalis Gaertn. by eirect bioautography method. Int J Phar Tech Res 2010; 2: 1547-1549.

[19] Gupta SK, Banerjee AB. Screening of selected West Bengal plants for antifungal activity. Econ Bot 2008; 26(3): 255-259.

[20] Suresh M, Rath PK, Panneerselvam A, Dhanasekaran D, Thajuddin N. Antifungal activity of selected indian medicinal plant salts. J Global Pharma Technol 2010; 2(4): 71-74.
[21] Parekh J, Chanda S. In vitro antifungal activity of methanol extracts of some Indian medicinal plants against pathogenic yeast and moulds. African J Biotechnol 2008; 7(23): 43494353.

[22] Patel M, Coogan MM. Antifungal activity of the plant Dodonaea viscosa var. angustifolia on Candida albicans from HIVinfected patients. J Ethnopharmacol 2008; 118(1): 173-176.

[23] Govindachari TR, Suresh G, Gopalakrishnan G, Balaganesan B, Masilamani S. Identification of antifungal compounds from the seed oil of Azadirachta Indica. Phytoparasitica 1998; 26(2): 109-116.

[24] Srinivasan D, Nathan S, Suresh T, Lakshmana Perumalsamy P. Antimicrobial activity of certain Indian medicinal plants used in folkloric medicine. J Ethnopharmacol 2001; 74: 217- 220.

[25] Duraipandiyan V, Ignacimuthu S, Gnanasekaran M. Antifungal activity of triterpenoid isolated from Azima tetracantha leaves. Folia Histochem Cytolbia 2010; 48: 311-313.

[26] CSIR. Wealth of India, publications \& information directory. New Delhi, India: CSIR; 1998; 164

[27] Nadkarni, K.M., and Nadkarni, A.K. Indian Materia Medica with Ayurvedic, Unani-Tibbi Siddha, Allopathic, Homeopathic Naturopathic and Home remedies, Popular Prakashan private Limited, Bombay, India, (1999) ISBN No.81-7154-142-9; I: 746-747.

[28] Mukherjee, P.K. Extraction of Herbal drugs quality control of Herbal Drugs Business. Horizon Publication, 2nd Ed., (2005) 381-420.

[29] NCCLS. Reference method for broth dilution antifungal susceptibility testing of filamentous fungi. Approved standard M38-A. Wayne, Pa: National Committee for Clinical Laboratory Standards; 2002.

[30] Shimada T.Salivary proteins as a defense against dietary tannins. J. Chem. Ecol. (2006) 32 (6): 1149-1163.

[31] Parekh J, Chanda S. In vitro antibacterial activity of crude methanol extract of Woodfordia fruticosa Kurz flower (Lythacease). Braz. J. Microbiol (2007) 38: 2.

[32] Dharmananda S. Gallnuts and the uses of Tannins in Chinese Medicine. In: Proceedings of Institute for Traditional Medicine, Portland, Oregon (2003).

[33] Nobori T, Miurak K, Wu DJ, Takabayashik LA, Carson DA. Deletion of the cyclin-dependent kinase- 4 inhibitor gene in multiple human cancers. (1994) Nature 368 (6473): 753-756.

[34] Quinlan MB, Quinlan RJ, Nolan JM. Ethnophysiology and herbal treatments of intestinal worms in Dominica, West Indies. J. Ethanopharmacol (2000)80: 75-83.

[35] Hodek P, Trefil P, Stiborova M. Flavonoids - Potent and versatile biologically active compounds interacting with cytochrome P450 (2002) Chemico-Biol. Intern. 139(1): 1-21. 